\title{
A deletion of one nucleotide results in functional deficiency of apolipoprotein CII (apo CII Toronto)
}

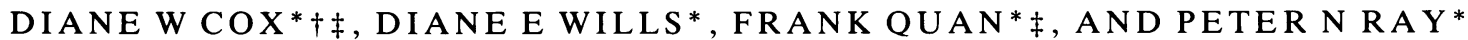 \\ From ${ }^{*}$ The Research Institute, The Hospital for Sick Children, 555 University Avenue, Toronto M5G $1 X 8$; \\ and the Departments of Paediatrics $\dagger$ and Medical Genetics $\ddagger$, University of Toronto, Toronto, Canada.
}

summary Apolipoprotein CII Toronto is a mutant non-functional apo CII resulting in apo CII deficiency. A portion of the mutant apo CII gene was cloned into lambda gt10 and subclones were sequenced. A deletion of one base was found in the codon for amino acid Thr68, resulting in alteration of six amino acids and premature termination of the protein at amino acid 74 .

Apolipoprotein CII (apo CII), a major apolipoprotein of chylomicrons and VLDL, and a component of $\mathrm{HDL}$, is the cofactor for the activation of lipoprotein lipase. Lipoprotein lipase, found mainly in adipose tissue and muscle, hydrolises plasma triglycerides at the surface of capillary endothelium allowing their further transport: The requirement for apo CII in this lipolysis was shown in a patient with no functional apo CII, who had marked fasting chylomicronaemia, hypertriglyceridaemia, and chronic pancreatitis. ${ }^{1}$ The deficiency, which we have identified in 14 subjects in a single kindred, is inherited as a autosomal recessive trait, in which homozygotes have 10 to 20 times the normal amount of plasma triglycerides, a lower ratio than normal of apo CII/CIII in VLDL, and minimal lipoprotein lipase activation. ${ }^{2} 3$ The mutant apo CII, apo CII Toronto, has an isoelectric point of 5.54 for the major component, compared with 4.88 for normal apo CII. ${ }^{4}$

The normal apo CII gene has been cloned and its genomic structure determined. ${ }^{5}$ We report here the cloning and sequencing of exons IV and $\mathrm{V}$ of the mutant apo CII Toronto gene. A single base pair

Received for publication 17 December 1987

Revised version accepted for publication 19 February 1988. deletion results in a frame shift, with an alteration of six terminal amino acids and premature termination of the protein.

\section{Materials and methods}

DNA was isolated from the buffy coat of blood collected in EDTA $^{6}$ from an affected homozygote (VI.II), described previously. ${ }^{2}$ The cloning and sequencing strategy was based on the structure of the normal apo CII gene, as described by Wei et $^{5} l^{5}$ (fig 1). The $3.5 \mathrm{~kb} \mathrm{EcoRI} \mathrm{fragment} \mathrm{contains} \mathrm{the}$ complete gene, except for a small portion of the $3^{\prime}$ untranslated region. DNA $(200 \mu \mathrm{g})$ was digested with EcoRI and subjected to electrophoresis in low melt agarose. DNA of fragment size 2.5 to $5 \mathrm{~kb}$ was recovered from the gel, passed through a NACS (BRL) column, ethanol precipitated, and ligated into EcoRI digested $\lambda$ gt10. Ligated DNA was packaged with an in vitro packaging kit (Gigapak), and plated in $E$ coli $\mathrm{C} 600$. The resulting genomic library of $6 \times 10^{5}$ pfu was screened ${ }^{7}$ using an apo CII cDNA clone, $\mathrm{A} 12,{ }^{8}$ kindly provided by $\mathrm{O}$ Mykelbost and S E Humphries. This cDNA clone contained 320 base pairs of the apo CII gene, beginning within exon III (fig 1). The apo CII insert was nick

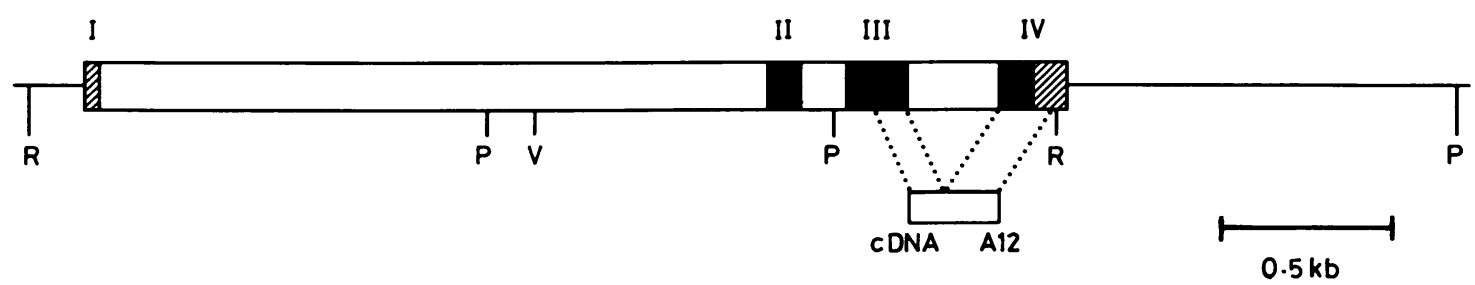

FIG 1 Structure of the normal apo CII gene, based on sequence data. ${ }^{6}$ Untranslated regions are cross hatched, exons are solid. The region included in clone $A 12^{8}$ is shown. $R=E c o R I, P=P s t I, V=P v u I I$. 
translated, using an Amersham kit, with ${ }^{32} \mathrm{PdCTP}$. Positive plaques were picked and purified by standard procedures. ${ }^{9}$

DNA was isolated from B5, one of four recombinants isolated from the library. Restriction fragments carrying exon IV of the apo CII gene were cloned into pSP64 and pSP65 for sequencing. We selected this portion of the mutant gene for sequencing since the mutant protein is slightly smaller than the normal, ${ }^{4}$ and the defect was most likely to be in the terminal portion required for function. The $3 \cdot 5$ $\mathrm{kb}$ EcoRI fragment from clone B5 was purified by agarose gel electrophoresis and digested with PstI, producing a $0.7 \mathrm{~kb}$ fragment containing exons III and IV; which was subcloned into vector pSP65. A $400 \mathrm{bp}$ fragment containing exon IV was obtained by cleaving the plasmid with HindIII and treating with exonuclease III and S1 nuclease, ${ }^{10}$ then EcoRI. The resulting fragment was subcloned into HincII-EcoRI cut pSP64. This strategy allowed sequencing in pSP65 from the 3' EcoRI site towards the 5' region of the gene. The exonuclease digested fragment allowed sequencing of the opposite strand from $5^{\prime}$ to $3^{\prime}$ through part of exon IV.

DNA sequencing was performed by the dideoxy chain termination method ${ }^{11}$ on double stranded DNA prepared by a rapid alkaline lysis method using an SP6 primer. ${ }^{12}$

A TaqI site polymorphism has been detected $3^{\prime}$ of the apo CII gene, using a cDNA probe. ${ }^{13}$ Frequencies in the normal population are 0.59 for a $3.8 \mathrm{~kb}$ fragment and 0.41 for a $3.5 \mathrm{~kb}$ fragment. Blot hybridisation was carried out on TaqI digested DNA from five affected homozygotes to identify which polymorphic fragment was present.

\section{Results}

The recombinant clone used for sequencing, B5, was identified as the appropriate fragment. Digestion of B5 with restriction endonucleases EcoRI, BamHI, $P v u \mathrm{II}, B g l \mathrm{II}$, and $P s t \mathrm{I}$ produced fragments predicted from the genomic map (fig 1). Southern blot analysis of EcoRI and PstI digested DNA fragments showed appropriate sized fragments when hybridised to probe A12.

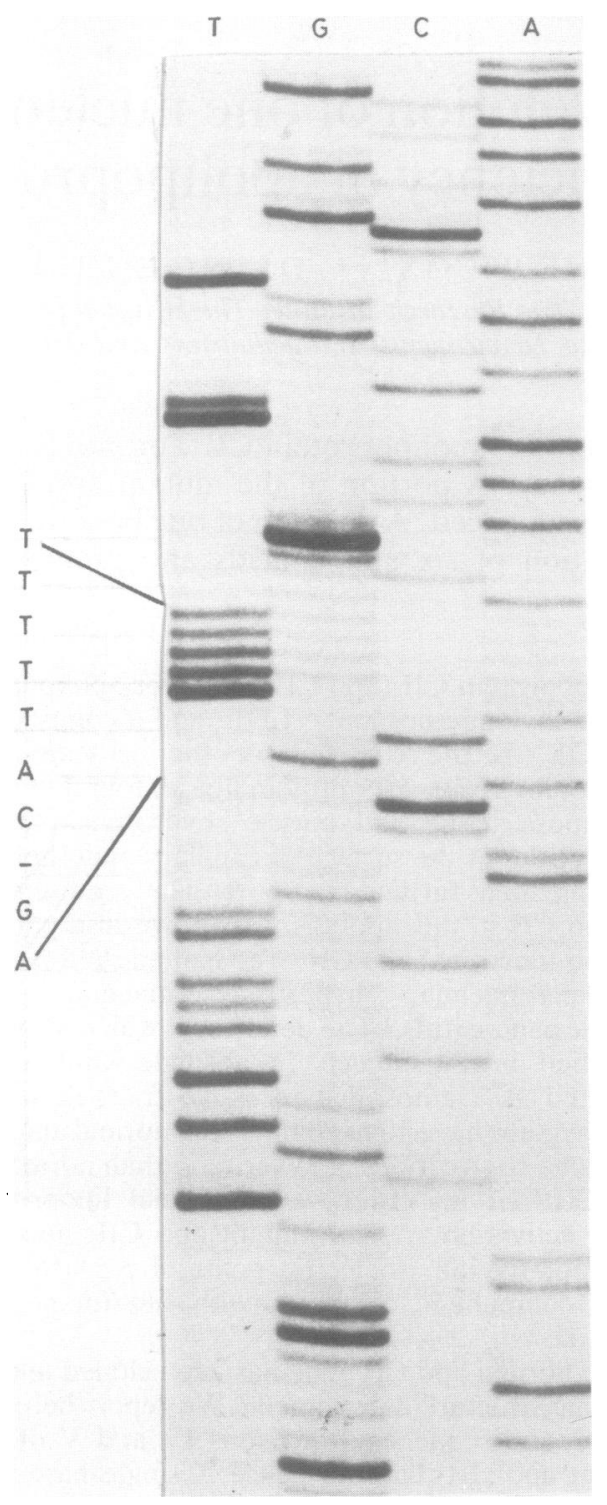

FIG 2 Portion of a sequencing gel showing the nucleotide sequence in apo CII Toronto in the region of the mutation.

TABLE 1 Amino acid residues and corresponding codons beginning at amino acid residue 67 to the stop codon at the COOH terminus, for normal apo CII and apo CII Toronto.

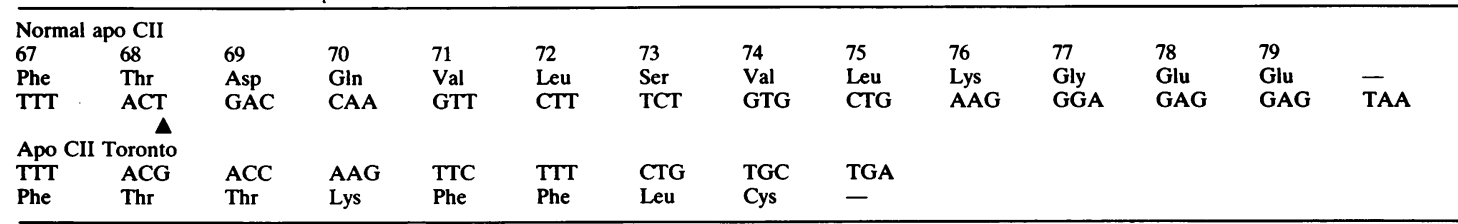


The DNA sequence was obtained from the region $26 \mathrm{bp} \mathrm{5}$ to exon IV to $230 \mathrm{bp} \mathrm{5'}$ of the EcoRI site at the end of the non-translated region in exon IV, and confirmed on the opposite strand. A portion of the sequencing gel is shown in fig 2 . In the mutant gene, a thymine in the third position of the ACT codon for Thr68 has been deleted, causing a frame shift. Results of this frame shift are shown in table 1. Amino acid 68 is unaltered; however, all amino acids after the frame shift are changed, with a premature termination at amino acid 74 instead of at the normal amino acid 79. A hydropathy plot of the mutant protein compared with the normal, using the Pustell sequence analysis program (IBI) (data not shown), showed that the absence of the five terminal amino acids produces a mutant protein with a more hydrophobic terminus.

Blot hybridisation of TaqI digested DNA indicated that all five affected homozygotes were homozygous for the $3.8 \mathrm{~kb}$ fragment.

\section{Discussion}

Deletion of a single base results in a marked alteration of apo CII Toronto from the normal apo CII. The amino acid sequence predicted from the mutant DNA sequence confirms the recent report of the protein sequence of apo CII Toronto, determined after our sequencing studies were in progress. ${ }^{14}$ However, the base pair deletion is in the codon for amino acid 68 , and not in codon 69 as was predicted from the protein sequence. ${ }^{14}$

The additional terminal glutamic acid residues in the normal apo CII account for the lower pI (4-88) in comparison with that of apo CII Toronto (5.54).

Three functional domains of apo CII have been postulated through the study of peptide fragments. ${ }^{15}$ These studies indicate that the possible lipid binding domain consists of residues 13 to 22,29 to 40 , and 43 to 52 . The lipoprotein lipase activation domain includes residues 56 to 67 . Residues 65 to 75 are predicted to constitute a lipoprotein lipase binding domain. The last three residues, 77 to 79 , are apparently required for lipase activation, and their deletion has previously been reported to lead to complete inactivation of apo CII. ${ }^{5}$ Apo CII Toronto lacks residues 75 to 79 and is completely inactive, as predicted. The differences at the $\mathrm{COOH}$ terminus between the mutant and normal apo CII would be predicted to alter the tertiary conformation of the protein, and perhaps prevent the binding of apo CII to lipoprotein lipase, thus preventing activation. An alteration in the physical conformation is compatible with the observation that antibody to apo CII apparently binds less firmly to apo CII Toronto than to the normal apo CII, at least when the complex is subjected to electrophoresis (W C Breckenridge, 1987, personal communication). However, antigenantibody binding takes place in solid medium, as in two dimension electrophoresis. ${ }^{4}$ Premature termination of the protein may interfere with binding of both lipoprotein lipase and antibody.

Since this mutation accounts for charge and functional changes, any other nucleotide alterations present in exons not sequenced are unlikely, if present, to be functionally important.

At least eight other families with apo CII deficiency have been described (table 2). No mutants for which the pI of the mutant apo CII was reported or could be estimated from a published photo appeared to be identical to apo CII Toronto. Because of linkage disequilibrium throughout the region of the apo CII gene and the flanking polymorphism, the presence of different sizes of TaqI fragments could indicate the presence of different mutant alleles. Alleles in cases 1 and 6 are associated with the 3.8 kb Taq fragment and in case 5 with the $3.5 \mathrm{~kb}$ fragment, the only cases in which the associated polymorphism has been reported. The use of haplotypes of both TaqI and BgIII polymorphisms flanking the apo CII gene ${ }^{26}$ would be helpful in identifying potential different mutations. Case num-

TABLE 2 Patients (probands) with apolipoprotein CII deficiency.

\begin{tabular}{|c|c|c|c|c|c|c|}
\hline $\begin{array}{l}\text { Case } \\
\text { No }\end{array}$ & $\begin{array}{l}\text { CII } \\
\text { name }\end{array}$ & Sex & $\begin{array}{l}\text { Age of } \\
\text { proband at } \\
\text { ascertainment }\end{array}$ & $\begin{array}{l}\text { Ethnic } \\
\text { origin }\end{array}$ & $\begin{array}{l}\text { Mutant } \\
\text { protein } \\
\text { by } I E F^{*}\end{array}$ & Refs \\
\hline 1 & Toronto & $\mathbf{M}$ & 59 & British & $+(p I 5 \cdot 5)$ & 1,2 \\
\hline 2 & & $\mathbf{F}$ & 13 & Japanese & $?$ & 16 \\
\hline 3 & & $\mathbf{F}$ & 2 & Italian (?) & $+?$ & 17 \\
\hline 4 & & $\mathbf{F}$ & 30 & British (?) & & 18 \\
\hline 5 & & $\mathbf{M}$ & 33 & Dutch & $+(\downarrow \mathrm{pI}) \dagger$ & 19,20 \\
\hline 6 & Padova & $\mathbf{M}$ & 41 & Italian & $+(\mathrm{pI} \sim 4.95) \dagger$ & 21,22 \\
\hline 7 & Bethesda & $\mathbf{F}$ & 11 & American & $+(\mathrm{pI}<4.9)$ & 22,23 \\
\hline 8 & & $\mathbf{M}$ & 5 & Puerto Rican & - & 24 \\
\hline 9 & St Michaels & $\mathbf{F}$ & 54 & Anglo-Saxon & +(forms dimers) & 25 \\
\hline
\end{tabular}

*Normal pI of major band 4.88 .

+ Based on appearance of gel in publication; $+=$ protein present. 
bers $1,5,6,8$, and 9 appear to result from different mutations.

This study was supported by a grant from the Heart and Stroke Foundation of Ontario. We thank $\mathrm{O}$ Myklebost (now at Rikshospitalet, Oslo) and S Humphries (St Mary's Hospital, London) for the gift of apo CII cDNA clones, Philip Connelly for helpful discussion, and Dr Alick Little, Director of the Lipid Research Clinic, for his continuing interest and support.

\section{References}

${ }^{1}$ Breckenridge WC, Little JA, Steiner G, Chow A, Poapst M. Hyperpertriglyceridemia associated with a deficiency of apolipoprotein C-II. N Engl J Med 1978;298:1265-73.

2 Cox DW, Breckenridge WC, Little JA. Inheritance of apolipoprotein C-II deficiency with hypertriglyceridemia and pancreatitis. N Engl J Med 1978;229:1421-4.

${ }^{3}$ Little JA, Cox D, Breckenridge WC, McGuire VM. In: Atherosclerosis $V$. New York: Springer-Verlag, 1980:671-4.

${ }^{4}$ Maguire GF, Little AJ, Kakis G, Breckenridge WC. Apolipoprotein C-II deficiency associated with nonfunctional mutant forms of apolipoprotein C-II. Can J Biochem Cell Biol 1984;62:847-52.

5 Wei CF, Tsao YK, Robberson DL, Gotto AM Jr, Brown K, Chan L. The structure of the human apolipoprotein C-II gene. J Biol Chem 1985;260:15211-21.

6 Madisen L, Hoar DI, Holroy CD, Crisp M, Hodes ME. DNA banking: the effects of storage of blood and isolated DNA on the integrity of DNA. Am J Med Genet 1987;27:379-90.

7 Benton WD, Davis RW. Screening $\lambda$ gt recombinant clones by hybridization to single plaques in situ. Science 1977;166:180-2.

${ }^{8}$ Myklebost $\mathrm{O}$, Williamson B, Markham AF, et al. The isolation and characterization of cDNA clones for human apolipoprotein CII. J Biol Chem 1984;259:4401-4.

9 Maniatis T, Fritsch EF, Sambrook J. Molecular cloning. A laboratory manual. New York: Cold Spring Harbour Laboratory, 1982.

${ }^{10}$ Guo L, Yang RCA, Wu R. An improved strategy for rapid direct sequencing of both strands of long DNA molecules cloned in a plasmid. Nucleic Acids Res 1983;11:5521-40.

1 Sanger F, Nicklen S, Coulson AR. DNA sequencing with chain terminating inhibitors. Proc Natl Acad Sci USA 1977;74:5463-7.

12 Korneluk RG, Quan F, Gravel RA. Rapid and reliable dideoxy sequencing of double-stranded DNA. Gene 1985;40:317-23.

13 Humphries SE, Jowett NI, Williams L, et al. A DNA poly- morphism adjacent to the human apolipoprotein CII gene. Mol Biol Med 1983;1:463-71.

14 Connelly PW, Maguire GF, Hofmann T, Little JA. Structure of apolipoprotein C-II Toronto, a nonfunctional human apolipoprotein. Proc Natl Acad Sci USA 1986;83:270-3.

15 Kinnunen PKJ, Jackson RL, Smith LC, Gotto AM Jr, Sparrow JT. Activation of lipoprotein lipase by native and synthetic fragments of human plasma apolipoprotein C-II. Proc Natl Acad Sci USA 1987;74:4848-51.

16 Yamamura T, Sudo H, Katsunori I, Yamamoto A. Familial type I hyperlipoproteinemia caused by apolipoprotein C-II deficiency. Atherosclerosis 1979;34:53-65.

17 Capurso A, Pace L, Bonomo L, et al. New case of apoprotein C-II deficiency. Lancet 1980;i:268.

${ }^{18}$ Miller NE, Rao SN, Alaupovic P, et al. Familial apolipoprotein CII deficiency: plasma lipoproteins and apolipoproteins in heterozygous and homozygous subjects and the effects of plasma infusion. Eur J Clin Invest 1981;11:69-76.

19 Stalenhoef AFH, Casparie AF, Demacker PNM, Stouten JYJ, Lutterman JA, van't Laar A. Combined deficiency of apolipoprotein C-II and lipoprotein lipase in familial hyperchylomicronemia. Metabolism 1981;30:919-26.

20 Humphries SE, Williams L, Myklebost O, et al. Familial apolipoprotein CII deficiency: a preliminary analysis of the gene defect in two independent families. Hum Genet 1984;67:151-5.

21 Baggio G, Manzato E, Gabelli C, et al. Apolipoprotein C-II deficiency syndrome. J Clin Invest 1986;7:520-7.

22 Fojo SS, Law SW, Sprecher DL, Gregg RE, Baggio G, Brewer HB Jr. Analysis of the apoC-II gene in apoC-II deficient patients. Biochem Biophys Res Commun 1984;124:308-13.

${ }^{23}$ Sprecher DL, Taam L, Brewer HB Jr. Two-dimensional electrophoresis of human plasma apolipoproteins. Clin Chem 1984;30:2084-92.

24 Saku F, Cedres C, McDonald B, et al. C-II anapolipoproteinemia and severe hypertriglyceridemia. Am J Med 1984;77:45761.

${ }^{25}$ Connelly PW, Maguire GF, Little JA. Familial apolipoprotein CII deficiency associated with premature vascular disease. J Clin Invest (in press).

${ }^{26}$ Wallis C, Donald JA, Forrest LA, Williamson R, Humphries $\mathrm{SE}$. The isolation of a genomic clone containing the apolipoprotein CII gene and the detection of linkage disequilibrium between two common DNA polymorphisms around the gene. Hum Genet 1984;68:286-9.

Correspondence and requests for reprints to $\mathrm{Dr}$ D W Cox, The Research Institute, The Hospital for Sick Children, 555 University Avenue, Toronto, Canada M5G 1X8. 